\title{
Carryover of Common Corn and Soybean Herbicides to Various Cover Crop Species
}

\author{
Cody D. Cornelius, and Kevin W. Bradley*
}

The recent interest in cover crops as component of Midwest corn and soybean production systems has led to the need for additional research, including the effects of residual corn and soybean herbicide treatments on fall cover crop establishment. Field studies were conducted in 2013, 2014, and 2015 in Columbia, Missouri to investigate the effects of common residual herbicides applied in corn and soybean on establishment of winter wheat, tillage radish, cereal rye, crimson clover, winter oat, Austrian winter pea, Italian ryegrass, and hairy vetch. Cover crops were evaluated for stand and biomass reduction $28 \mathrm{~d}$ after emergence (DAE). Rainfall from herbicide application to cover crop seeding date was much greater in 2014 and 2015, which resulted in less carryover in these years compared to 2013. When averaged across all herbicides evaluated in these experiments, the general order of sensitivity of cover crops to herbicide carryover, from greatest to least was Austrian winter pea $=$ crimson clover $>$ oilseed radish $>$ Italian ryegrass $>$ hairy vetch $>$ wheat $>$ winter oat $>$ cereal rye. Cereal rye had the fewest instances of biomass or stand reduction with only four out of the 27 herbicides adversely effecting establishment. Pyroxasulfone consistently reduced Italian ryegrass and winter oat biomass at least $67 \%$ in both the corn and soybean experiments. In the soybean experiment, imazethapyr- and fomesafen-containing products resulted in severe stand and biomass reduction in both years while flumetsulam-containing products resulted in the greatest carryover symptoms in the corn experiment. Results from these experiments suggest that several commonly used corn and soybean herbicides have the potential to hinder cover crop establishment, but the severity of damage will depend on weather, cover crop species, and the specific herbicide combination.

Nomenclature: Flumetsulam; fomesafen; imazethapyr; pyroxasulfone; Austrian winter pea, Pisum sativum L; cereal rye, Secale cereale L; corn, Zea mays L, crimson clover, Trifolium incarnatum L; hairy vetch, Vicia villosa Roth; Italian ryegrass, Lolium perenne L. ssp. multiflorum (Lam.) Husnot; oat, Avena sativa L; oilseed radish, Raphanus sativus L; soybean, Glycine max (L.) Merr; wheat, Triticum aestivum L. Key words: Herbicide carryover, residual herbicides, stand reduction.

\begin{abstract}
El reciente interés en el uso de cultivos de cobertura como componente de los sistemas de producción de maíz y soja en el medio oeste ha llevado a la necesidad de realizar investigación adicional que incluya los efectos de los tratamientos de herbicidas residuales en maíz y soja sobre el establecimiento de cultivos de cobertura en el otońo. Estudios de campo fueron realizados en 2013, 2014, y 2015 en Columbia, Missouri, para investigar los efectos de herbicidas residuales comunes aplicados en maíz y soja sobre el establecimiento de trigo de invierno, rábano, centeno, Trifolium incarnatum, avena de invierno, guisante, Lolium perenne, y Vicia villosa. Los cultivos de cobertura fueron evaluados por reducciones en el establecimiento y la biomasa 28 d después de la emergencia(DAE). La precipitación desde la aplicación del herbicida hasta la siembra del cultivo de cobertura fue mucho mayor en 2014 y 2015 , lo que resultó en menos efecto residual de los herbicidas en estos años al compararse con 2013. Cuando se promediaron todos los herbicidas evaluados en estos experimentos, el orden general de sensibilidad de los cultivos de cobertura a los residuos de herbicidas de mayor a menor fue guisantes $=T$. incarnatum $>$ rábano $>L$. perenne $>V$. villosa $>$ trigo $>$ avena de invierno $>$ centeno. El centeno tuvo el menor número de instancias en que se redujo la biomasa o el número de plantas establecidas con solamente cuatro de 27 herbicidas afectando negativamente el establecimiento. Pyroxasulfone redujo consistentemente la biomasa de L. perenne y avena de invierno al menos $67 \%$ en los experimentos de maíz y soja. En el experimento de soja, productos que contenían imazethapyr y fomesafen resultaron en reducciones severas en el establecimiento y la biomasa en ambos ańos mientras que productos conteniendo flumetsulam resultaron en los mayores síntomas de daño por residuos de los herbicidas en el experimento de maíz. Los resultados de estos experimentos sugieren que varios herbicidas comúnmente usados en maíz y soja tienen el potencial de reducir el establecimiento de cultivos de cobertura, pero la severidad del daño dependerá del clima, la especie de cultivo de cobertura, y la combinación específica de herbicidas.
\end{abstract}

\footnotetext{
DOI: 10.1614 /WT-D-16-00062.1

*Graduate Student and Associate Professor, Division of Plant Science, 201 Waters Hall, University of Missouri, Columbia, MO 65211. Corresponding author's E-mail: bradleyke@missouri.edu.
} 
According to a survey of cover crop users in the United States, the second biggest challenge to the adoption of cover crops is successful establishment in a corn or soybean production system (SARE 2014). Additionally, certain residual herbicides applied in a corn and soybean rotation have the potential to carry over in the soil and inhibit successful establishment of fall-seeded cover crops (Curran et al. 1996). The adoption of no-tillage systems in recent years has shifted weed control tactics away from an emphasis on tillage and towards the use of non-selective pre-plant and residual herbicides that allow growers to plant into weed-free fields and keep the fields weed free for several weeks after planting. In addition, overreliance on glyphosate has resulted in an increase in glyphosate- and multiple-herbicide resistant weeds (Heap 2016), leading many growers to apply additional residual, soil-applied herbicides in order to achieve adequate weed control (Hager et al. 2003; Riggins and Tranel 2012). For example, the use of diphenyl ether and dinitroaniline herbicides increased by approximately $24 \%$ in the United States from 2006 to 2012, while the percentage of soybean acres that received at least one pre-emergence residual herbicide application increased by approximately $19 \%$ from 2001 to 2006 (USDA 2015).

Soil characteristics such as $\mathrm{pH}$, organic matter, cation exchange capacity, and soil texture have been shown to play a major role in the degradation of soil-applied herbicides. Soil persistence of herbicides like imazaquin and imazethapyr has been found to increase as soil $\mathrm{pH}$ decreases, as a result of greater adsorption that results in the herbicide being less available for microbial degradation (Cantwell et al. 1989; Loux and Reese 1993). In soils with greater than 3\% organic matter, herbicide carryover potential is increased (Curran 2001). Soil texture also plays a role in the likelihood of herbicide carryover; Westra et al. (2014) found that the half-life (DT ${ }_{50}$ ) of pyroxasulfone ranged from 104 to $134 \mathrm{~d}$ in a fine clay loam soil and from 46 to $48 \mathrm{~d}$ in a fine sandy loam soil. In addition, Kerr et al. (2004) found that herbicide persistence is more likely when soil cation exchange capacity levels are higher. Environmental factors, such as the amount of rainfall and the temperature after application, also play a major role in herbicide degradation. For example, Bauer and Calvet (1999) found that the dissipation rate of simazine, atrazine, diuron, and sulcotrione increased as soil moisture increased, while Zimdahl et al. (1984) and
Tharp and Kells (2000) showed that pendimethalin degraded more quickly with increasing amounts of rainfall, causing less injury to subsequent crops. In addition, Westra et al. (2014) observed that, regardless of sand or clay content, pyroxasulfone and $S$-metolachlor dissipation rates were positively correlated with the amount of irrigation. In reduced tillage systems, research results on the effects of environmental factors on herbicide carryover have been mixed, but most authors indicate that climatic variables such as rainfall and temperature have a greater impact on herbicide carryover than does residue management (Kells et al. 1990; Locke and Bryson 1997).

Few studies have examined the potential carryover effects of common soil residual herbicides applied to corn and soybean to fall-seeded cover crops. In one Michigan study, pendimethalin and metolachlor were found to reduce stand densities of Italian ryegrass by $46 \%$ and $94 \%$, respectively, $40 \mathrm{~d}$ after treatment (Tharp and Kells 2000). Hanson and Thill (2001) found that imazethapyr applied to lentil (Lens culinaris Medik) and Austrian winter pea reduced the biomass of a subsequently planted wheat crop by $35 \%$ to $51 \%$ (Hanson and Thill 2001). Walsh et al. (1993a) reported winter wheat injury of $25 \%$ five months after an application of clomazone in soybean. These same authors also reported cotton injury as high as $33 \%$ following imazaquin, and corn and grain sorghum [Sorghum bicolor (L.) Moench ssp. bicolor] injury from $7 \%$ to $24 \%$ following metribuzin + chlorimuron, imazaquin, clomazone, or imazethapyr. Walsh et al. (1993b) also found that a $2 \times$ rate of clomazone reduced spring-planted winter oat biomass by $44 \%$, while imazaquin and imazethapyr did not cause significant carryover symptoms. Overall, few studies have examined the effects of within-season applications of residual herbicides on fall-seeded cover crops, and many of those that have been conducted have not investigated some of the species that are currently being promoted and/or investigated for inclusion in corn and soybean production systems. Therefore, the objectives of this research were to determine the potential of common corn and soybean residual herbicides to reduce stand densities and biomass of subsequent fall-seeded cover crop species.

\section{Materials and Methods}

General Trial Information. Field experiments were conducted in 2013 and repeated in 2014 and 
2015 in Boone County at the University of Missouri Bradford Research Center near Columbia, Missouri $\left(38^{\circ} 53^{\prime} 53.22^{\prime \prime} \mathrm{N}, 92^{\circ} 22^{\prime} 14.42^{\prime \prime} \mathrm{W}\right)$. The soil was a Mexico silt loam (fine, smectic, mesic Aeric Vertic Epiaqualf) with $2.3 \%$ organic matter and a $\mathrm{pH}$ of 6.5 in $2013,2.1 \%$ organic matter and a $\mathrm{pH}$ of 6.4 in 2014 , and $2.2 \%$ organic matter and a $\mathrm{pH}$ of 6.3 in 2015. Corn and soybean were planted into a no-till seedbed in rows spaced $76 \mathrm{~cm}$ apart at rates of 71,661 and 444,789 seeds ha ${ }^{-1}$, respectively. Corn herbicides were applied once corn reached the V2 stage of growth. Soybean herbicides were applied POST once the soybeans reached the V2 to V3 stage of growth, except in the case of flumioxazin, sulfentrazone, metribuzin, sulfentrazone + cloransulam, and chlorimuron, which were applied PRE based on crop safety requirements. Herbicides were applied using a $\mathrm{CO}_{2}$-pressurized backpack sprayer equipped with XR 8002 flat fan nozzle tips (Teejet ${ }^{\circledR}$, Spraying Systems Co., P.O. Box 7900, Wheaton, IL 60187) delivering $140 \mathrm{~L} \mathrm{ha}^{-1}$ at $117 \mathrm{kPa}$. All treatments were arranged in a split-plot design with four replications. Whole plots consisted of herbicide treatments, while subplots consisted of cover crop species. Subplots were 3 by $3 \mathrm{~m}$ in size. Dates of major field operations and specific rainfall between herbicide application and cover crop planting dates are shown in Table 1 . Monthly rainfall totals and average temperatures for each year are presented in Table 2. A list of all herbicide formulations evaluated and their respective application timing can be found in Table 3 . Following removal of the previous corn or soybean crop for forage, seven winter annual cover crops were planted on September 11, 12, and 10 in 2013, 2014, and 2015, respectively, at the following seeding rates: 'Roane' winter wheat at $135 \mathrm{~kg} \mathrm{ha}^{-1}$, cereal rye at $123 \mathrm{~kg} \mathrm{ha}^{-1}$, 'Marshall' Italian ryegrass at $28 \mathrm{~kg} \mathrm{ha}^{-1}$, winter oat at $78 \mathrm{~kg} \mathrm{ha}^{-1}$, crimson clover at $34 \mathrm{~kg}$ $\mathrm{ha}^{-1}$, Austrian winter pea at $56 \mathrm{~kg} \mathrm{ha}^{-1}$, hairy vetch at $34 \mathrm{~kg} \mathrm{ha}^{-1}$, and 'Tillage Radish' oilseed radish at $9 \mathrm{~kg} \mathrm{ha}^{-1}$. All cover crops were planted with a 750 no-till drill (Deere \& Company, 1 John Deere Place, Moline, IL 61265).

Treatment Evaluation and Data Collection. All cover crop species were evaluated for stand and biomass reduction $28 \mathrm{~d}$ after emergence (DAE). Stand counts were performed by counting all emerged plants within two $1 / 3 \mathrm{~m}^{2}$ quadrats in each subplot. In a similar manner, aboveground biomass was collected within one $1 / 3 \mathrm{~m}^{2}$ quadrat from each subplot. Biomass samples were weighed after being dried at $49 \mathrm{C}$ for $96 \mathrm{hr}$. Percent stand and biomass reductions were calculated by dividing the differences between the treated and non-treated plots by the non-treated plot values.

Statistical Analysis. All stand and biomass reduction data were analyzed in SAS ${ }^{\circledR}$ version 9.3 (SAS Institute Inc., Cary, NC) using the PROC GLIMMIX

Table 1. Dates of major field operations and rainfall following herbicide application in 2013, 2014, and 2015 at the University of Missouri Bradford Research Farm in Boone County, Missouri and at the Moberly Missouri site in Randolph County, Missouri. ${ }^{a}$

\begin{tabular}{lcc}
\hline & \multicolumn{2}{c}{ Date of operation and rainfall following herbicide application } \\
\cline { 2 - 2 } Field operation & 2013 & 2014 \\
\hline Corn experiment & & 2015 \\
$\quad$ Corn seeding date & $6 / 12$ & $5 / 19$ \\
$\quad$ Date of herbicide application & $6 / 26$ & $6 / 11$ \\
$\quad$ V2 & $9 / 11$ & $9 / 30$ \\
Cover crop seeding date & $96 \mathrm{~cm}$ & $9 / 13$ \\
Rainfall from herbicide application to cover crop seeding date & & $362 \mathrm{~cm}$ \\
Soybean experiment & $6 / 12$ & $6 / 3$ \\
$\quad$ Soybean seeding date & $6 / 13$ & $7 / 14$ \\
Dates of herbicide application & $7 / 2$ & $6 / 6$ \\
$\quad$ PRE & $9 / 11$ & $6 / 17$ \\
V2-V3 & & $9 / 11$ \\
Cover crop seeding date & $131 \mathrm{~cm}$ & $7 / 28$ \\
Rainfall from herbicide application to cover crop seeding date & $90 \mathrm{~cm}$ & $9 / 13$ \\
$\quad$ PRE & & $404 \mathrm{~cm}$ \\
$\quad$ POST V2-V3 & $358 \mathrm{~cm}$ \\
\hline
\end{tabular}

a Abbreviations: V2, two leaves; V2-V3, two to three leaves; PRE, pre-emergence; POST, post-emergence. 


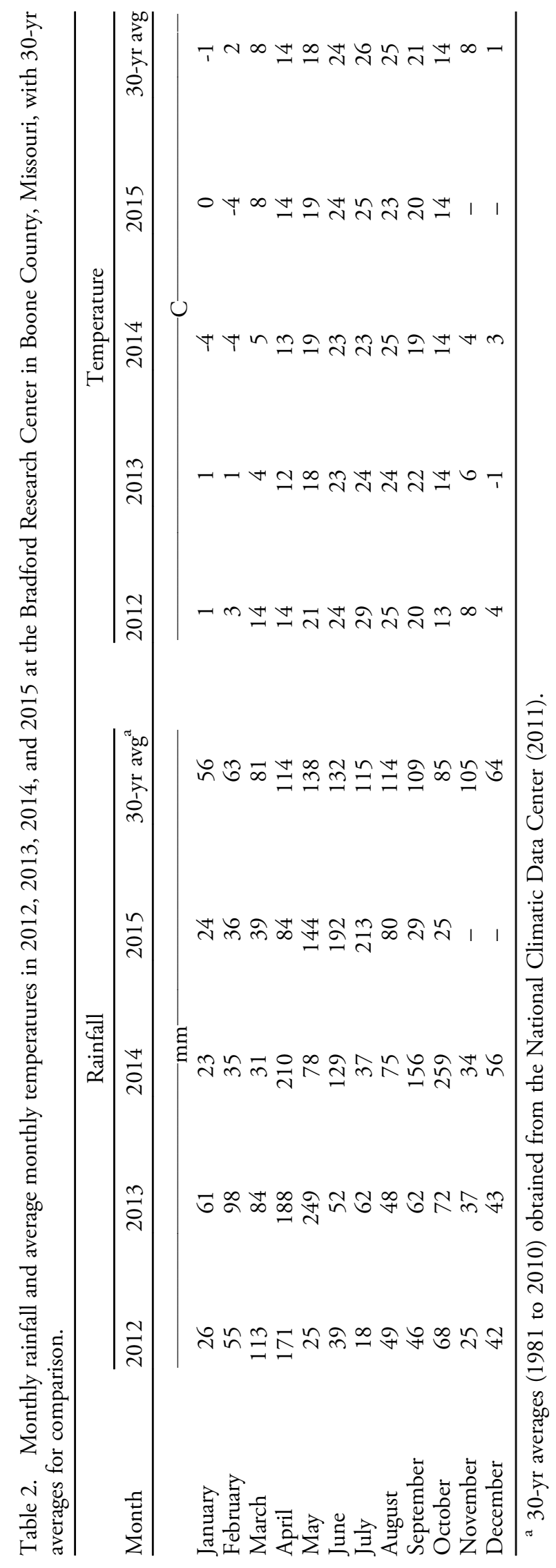

procedure. Herbicide treatment and cover crop species were considered fixed effects in the model, while environment and replicate were considered random effects. Results revealed significant interactions between years, likely due to the considerable differences in rainfall (Table 2); therefore, results are presented by year. Means were separated using Fisher's protected LSD at $\alpha=0.05$.

\section{Results and Discussion}

Carryover of Soybean Herbicides. In general, herbicide degradation is more rapid with adequate soil moisture and warm temperatures (Zimdahl 2007). In 2013 and 2015, there was a significant cover crop species by herbicide treatment interaction for biomass and stand reduction, but this interaction was not significant in 2014 (Table 4). This can be attributed to the fact that there was substantially more rainfall from the time of herbicide application to cover crop planting in 2014: from the time of the herbicide applications to the cover crop planting date, these plots received at least 268 and $186 \mathrm{~mm}$ more rainfall in 2014 than they did in 2013 and 2015, respectively (Table 1 ).

Winter wheat biomass was reduced in 2013 following imazethapyr, pyroxasulfone, and fomesafen + $S$-metolachlor treatment, but no significant carryover was observed in 2015 (Tables 5 and 6). Imazethapyr, pyroxasulfone, and fomesafen $+S$-metolachlor treatments resulted in a $26 \%$ to $41 \%$ reduction in winter wheat biomass in 2013. When averaged across all herbicide treatments, winter wheat biomass was reduced $28 \%$ in 2014, and no carryover was observed in 2015 (Table 7).

Oilseed radish density and biomass were reduced following fomesafen, imazethapyr, and fomesafen + $S$-metolachlor in 2013 and 2015 (Tables 5 and 6). In 2013, imazethapyr and fomesafen $+S$-metolachlor resulted in $62 \%$ to $76 \%$ oilseed radish biomass reduction, while fomesafen resulted in less biomass reduction $(51 \%)$ than imazethapyr, but a similar level to that provided by fomesafen $+S$-metolachlor. Additionally, sulfentrazone + cloransulam reduced oilseed radish biomass by $26 \%$ in 2013 , but no stand or biomass reduction were observed following this herbicide treatment in 2015, most likely due to the higher rainfall in 2015 compared to 2013 (Tables 1 and 2). Throughout both experiments, certain 
Table 3. Sources of herbicides used in the experiments

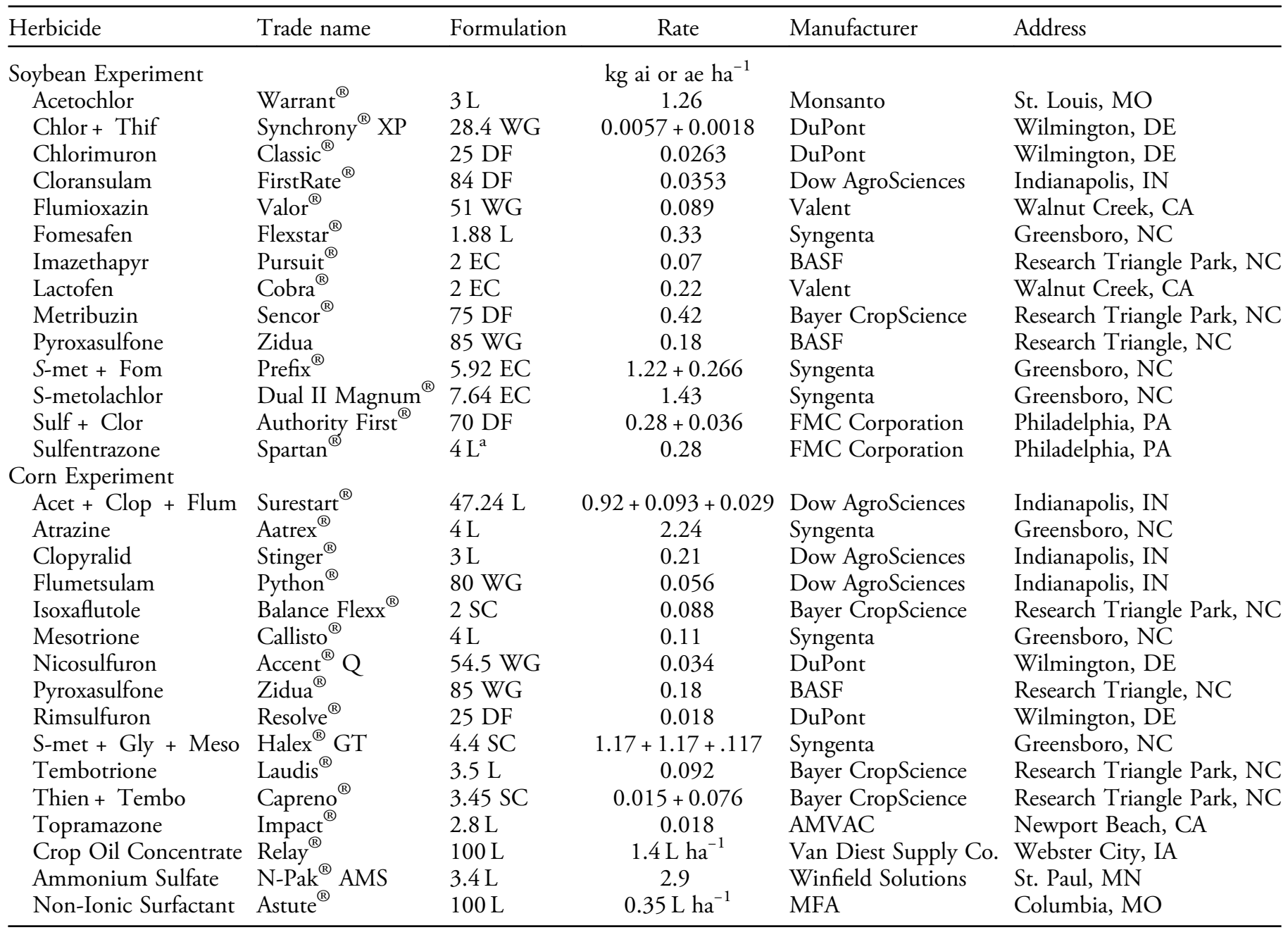

a Abbreviations: Chlor, chlorimuron; Thif, thifensulfuron; S-met, S-metolachlor; Fom, fomesafen; Sulf, sulfentrazone; Clor, cloransulam; Acet, acetochlor; Clop, clopyralid; Flum, flumetsulam; Gly, glyphosate; Meso, mesotrione; Thien, thiencarbazone; Tembo, tembotrione; L, liquid; WG, water-dispersible granule; DF, dry flowable; EC, emulsifiable concentrate; SC, soluble concentrate.

herbicides resulted in cover crop biomass reduction but no significant stand reduction, as was the case with sulfentrazone + cloransulam in 2013. This response is not uncommon, and is probably because the herbicides allowed seedlings to emerge, but as the seedlings developed their roots absorbed the herbicide residues resulting in injury and biomass reduction. In 2015, fomesafen, imazethapyr, and fomesafen $+S$-metolachlor resulted in 33\% to $43 \%$ oilseed radish biomass reduction. Oilseed radish stand reduction was the greatest, $41 \%$, following fomesafen, but stand reduction remained similar to imazethapyr and acetochlor; fomesafen $+S$-metolachlor also resulted in 19\% stand reduction. The consistent carryover effects of fomesafen-containing products and imazethapyr in oilseed radish can be correlated with the herbicides' extended half-life in clay soils (Cantwell et al. 1989; Loux and Reese 1993; Mueller et al. 2014; Shaner et al. 2014) and the sensitivity of this cover crop to low residue levels of these herbicides.

Cereal rye stand was not reduced by any herbicide treatment in either year (Tables 5 and 6). These results are similar to those of Smith et al. (2015), who reported that cereal rye was not impacted by commonly used soybean herbicides across two years in Wisconsin and Indiana. However, in 2013 cereal rye biomass was reduced by at least $24 \%$ following flumioxazin and cloransulam. In 2015, sulfentrazone 
Table 4. Summary of effects of cover crop species and herbicide treatment on cover crop biomass and stand density reduction 28 days after emergence of corn or soybean.

\begin{tabular}{|c|c|c|c|c|c|c|}
\hline Variable & \multicolumn{3}{|c|}{ Biomass reduction } & \multicolumn{3}{|c|}{ Stand reduction } \\
\hline Cover crop species & $<0.0001$ & 0.0348 & 0.2164 & 0.0006 & 0.0180 & $<0.0001$ \\
\hline Herbicide treatment & 0.0248 & 0.6737 & 0.0389 & $<0.0001$ & 0.0001 & 0.7387 \\
\hline Herbicide treatment $*$ cover crop & $<0.0001$ & 0.1402 & 0.9098 & $<0.0001$ & 0.9737 & 0.9859 \\
\hline Herbicide treatment & $<0.0001$ & $<0.0001$ & $<0.0001$ & 0.1123 & 0.7602 & $<0.0001$ \\
\hline Herbicide treatment $*$ cover crop & $<0.0001$ & 0.9476 & 0.0007 & 0.0190 & 0.9983 & 0.0002 \\
\hline
\end{tabular}

reduced cereal rye biomass by $33 \%$. In 2014, when averaged across all herbicide treatments, cereal rye biomass and stand density were reduced by $17 \%$ and $11 \%$, respectively (Table 7 ). At near neutral $\mathrm{pH}$, cloransulam has been shown to have a half-life as long as $200 \mathrm{~d}$, which would help to explain the observed carryover to cereal rye (Shaner et al. 2014).

Crimson clover stand or biomass was reduced following fomesafen and acetochlor in 2013 and 2015 (Tables 5 and 6). In 2013, crimson clover stand density was reduced by $23 \%$ following acetochlor. Biomass was similarly reduced by at least $29 \%$ following metribuzin, S-metolachlor, and acetochlor in 2013. In 2015, biomass was also reduced from $31 \%$ to $38 \%$ following sulfentrazone + cloransulam, fomesafen, imazethapyr, chlorimuron + thifensulfuron, and acetochlor in 2015. The consistent carryover observed from fomesafen can be attributed to the extended half-life of this herbicide. Acetochlor carryover to crimson clover is consistent with the $8 \mathrm{mo}$ rotational restriction listed on the herbicide label (Anonymous 2016f).

Winter oat stand density or biomass was reduced in 2013 and 2015 following imazethapyr and pyroxasulfone (Tables 5 and 6). Imazethapyr reduced winter oat biomass by $42 \%$ and $52 \%$ in 2013 and 2015, respectively, but stand density was not impacted in either year. Pyroxasulfone reduced winter oat stand density by $45 \%$ in 2015 , and reduced biomass by $68 \%$ in 2015 . In 2015 , winter oat biomass was also reduced by at least $31 \%$ following flumioxazin, acetochlor, and chlorimuron, while stand density was reduced $22 \%$ and $19 \%$ following fomesafen and sulfentrazone. When averaged across all cover crops, pyroxasulfone and imazethapyr resulted in a $32 \%$ and $25 \%$ reduction in stand density, respectively (Table 8). This consistent trend of pyroxasulfone carryover coincides with the results of Westra et al. (2014), who showed a pyroxasulfone half-life of 104 to $134 \mathrm{~d}$ in soils with high clay content.

Flumioxazin, metribuzin, fomesafen, and acetochlor reduced Austrian winter pea stand density or biomass in 2013 and 2015 (Tables 5 and 6). In 2013, flumioxazin, metribuzin, fomesafen, cloransulam, S-metolachlor, pyroxasulfone, and acetochlor reduced Austrian winter pea biomass by at least $26 \%$, but stand density was not affected by any herbicide except flumioxazin. In 2015, sulfentrazone, flumioxazin, metribuzin, fomesafen, and acetochlor reduced Austrian winter pea biomass between $28 \%$ and $37 \%$, while stand density was unaffected. Flumioxazin and sulfentrazone have been reported to have half-lives as long as 21 and 71 days, respectively, under field conditions (Mueller et al. 2014). In addition, flumioxazin, metribuzin, and fomesafen require at least a 4 mo rotational restriction before planting Austrian winter peas (Anonymous 2016b, 2016d, 2016e).

Italian ryegrass stand density and biomass were reduced by at least $57 \%$ and $67 \%$, respectively, in response to previous applications of pyroxasulfone in 2013 and 2015 (Tables 5 and 6). Bond et al. (2014) reported that $0.16 \mathrm{~kg}_{\mathrm{ai} \mathrm{ha}}{ }^{-1}$ pyroxasulfone provided $93 \%$ control of Italian ryegrass $180 \mathrm{~d}$ following a fall application. Therefore, the substantial reductions in Italian ryegrass stand and biomass can be attributed to the extended half-life and high level of sensitivity of this species to pyroxasulfone. In 2013, Smetolachlor also reduced Italian ryegrass biomass by $27 \%$, but no significant carryover injury was observed in 2015 following an in-season application 
Table 5. Influence of soybean herbicides on cover crop stand and biomass reduction 28 days after emergence in Columbia, Missouri in 2013.

\begin{tabular}{|c|c|c|c|c|c|c|c|c|c|c|c|c|c|c|c|c|}
\hline \multirow[b]{2}{*}{ Herbicide } & \multicolumn{2}{|c|}{$\begin{array}{l}\text { Winter } \\
\text { wheat }\end{array}$} & \multicolumn{2}{|c|}{$\begin{array}{l}\text { Oilseed } \\
\text { radish }\end{array}$} & \multicolumn{2}{|c|}{$\begin{array}{l}\text { Cereal } \\
\text { rye }\end{array}$} & \multicolumn{2}{|c|}{$\begin{array}{c}\text { Crimson } \\
\text { clover }\end{array}$} & \multicolumn{2}{|c|}{$\begin{array}{c}\text { Winter } \\
\text { oat }\end{array}$} & \multicolumn{2}{|c|}{$\begin{array}{c}\text { Austrian } \\
\text { winter pea }\end{array}$} & \multicolumn{2}{|c|}{$\begin{array}{c}\text { Italian } \\
\text { ryegrass }\end{array}$} & \multicolumn{2}{|c|}{$\begin{array}{l}\text { Hairy } \\
\text { vetch }\end{array}$} \\
\hline & Stand & Biomass & Stand & Biomass & Stand & Biomass & Stand & Biomass & Stand & Biomass & Stand & Biomass & Stand & Biomass & Stand & Biomass \\
\hline & & & & & & & & $-\% \operatorname{Red}$ & uction- & & & & & & & \\
\hline Acetochlor & 22 & 12 & 6 & 10 & 15 & 15 & 23 & 32 & 14 & 9 & 0 & 27 & 32 & 15 & 11 & 49 \\
\hline Chlorimuron & 27 & 13 & 7 & 9 & 14 & 7 & 2 & 4 & 13 & 0 & 18 & 0 & 17 & 4 & 14 & 8 \\
\hline Chlorimuron + thifensulfuron & 19 & 19 & 3 & 0 & 16 & 20 & 8 & 9 & 14 & 13 & 8 & 20 & 17 & 0 & 6 & 16 \\
\hline Cloransulam & 15 & 18 & 2 & 8 & 9 & 29 & 9 & 0 & 6 & 13 & 7 & 26 & 6 & 8 & 17 & 14 \\
\hline Flumioxazin & 27 & 10 & 6 & 15 & 18 & 24 & 14 & 29 & 3 & 0 & 8 & 38 & 19 & 2 & 6 & 24 \\
\hline Fomesafen & 22 & 13 & 28 & 51 & 5 & 16 & 27 & 8 & 8 & 5 & 17 & 26 & 11 & 0 & 1 & 19 \\
\hline Fomesafen $+S$-metolachlor & 21 & 41 & 32 & 62 & 19 & 31 & 15 & 3 & 6 & 4 & 8 & 15 & 12 & 11 & 15 & 11 \\
\hline Imazethapyr & 11 & 30 & 41 & 76 & 17 & 17 & 0 & 1 & 12 & 42 & 13 & 14 & 14 & 7 & 16 & 17 \\
\hline Lactofen & 7 & 12 & 6 & 6 & 14 & 11 & 7 & 5 & 12 & 14 & 12 & 10 & 6 & 10 & 9 & 6 \\
\hline Metribuzin & 43 & 13 & 2 & 3 & 22 & 23 & 11 & 13 & 9 & 7 & 23 & 32 & 20 & 4 & 11 & 40 \\
\hline Pyroxasulfone & 20 & 26 & 2 & 9 & 17 & 15 & 13 & 13 & 33 & 14 & 4 & 27 & 57 & 67 & 0 & 46 \\
\hline$S$-metolachlor & 38 & 18 & 5 & 4 & 18 & 12 & 20 & 43 & 13 & 7 & 21 & 43 & 14 & 27 & 15 & 31 \\
\hline Sulfentrazone & 33 & 11 & 6 & 0 & 17 & 5 & 4 & 19 & 3 & 0 & 7 & 3 & 9 & 0 & 9 & 13 \\
\hline Sulfentrazone + cloransulam & 13 & 9 & 18 & 26 & 3 & 10 & 6 & 7 & 14 & 0 & 2 & 8 & 5 & 0 & 7 & 9 \\
\hline LSD (0.05): & 22 & 23 & 22 & 23 & 22 & 23 & 22 & 23 & 22 & 23 & 22 & 23 & 22 & 23 & 22 & 23 \\
\hline
\end{tabular}

Table 6. Influence of soybean herbicides on cover crop stand and biomass reduction 28 days after emergence in Columbia, Missouri in 2015.

\begin{tabular}{|c|c|c|c|c|c|c|c|c|c|c|c|c|c|c|c|c|}
\hline \multirow[b]{2}{*}{ Herbicide } & \multicolumn{2}{|c|}{$\begin{array}{l}\text { Winter } \\
\text { wheat }\end{array}$} & \multicolumn{2}{|c|}{$\begin{array}{l}\text { Oilseed } \\
\text { radish }\end{array}$} & \multicolumn{2}{|c|}{$\begin{array}{c}\text { Cereal } \\
\text { rye }\end{array}$} & \multicolumn{2}{|c|}{$\begin{array}{c}\text { Crimson } \\
\text { clover }\end{array}$} & \multicolumn{2}{|c|}{$\begin{array}{c}\text { Winter } \\
\text { oat }\end{array}$} & \multicolumn{2}{|c|}{$\begin{array}{c}\text { Austrian } \\
\text { winter pea }\end{array}$} & \multicolumn{2}{|c|}{$\begin{array}{l}\text { Italian } \\
\text { ryegrass }\end{array}$} & \multicolumn{2}{|c|}{$\begin{array}{l}\text { Hairy } \\
\text { vetch }\end{array}$} \\
\hline & Stand & Biomass & Stand & Biomass & Stand & Biomass & Stand & Biomass & Stand & Biomass & Stand & Biomass & Stand & Biomass & Stand & Biomass \\
\hline & & & & & & & & - \% Red & luction & & & & & & & \\
\hline $\begin{array}{l}\text { Acetochlor } \\
\text { Chlorimuron }\end{array}$ & 4 & $\begin{array}{l}1 \\
5\end{array}$ & 24 & $\begin{array}{l}12 \\
19\end{array}$ & 2 & $\begin{array}{r}24 \\
0\end{array}$ & 5 & 38 & 7 & 31 & 0 & $\begin{array}{l}37 \\
15\end{array}$ & $\begin{array}{l}6 \\
3\end{array}$ & 22 & $\begin{array}{l}7 \\
7\end{array}$ & $\begin{array}{r}15 \\
0\end{array}$ \\
\hline Chlorimuron + thifensulfuron & $\begin{array}{l}1 \\
0\end{array}$ & 5 & $\begin{array}{l}20 \\
10\end{array}$ & $\begin{array}{r}19 \\
0\end{array}$ & $\begin{array}{l}4 \\
6\end{array}$ & 11 & $\begin{array}{l}2 \\
5\end{array}$ & $\begin{array}{l}22 \\
31\end{array}$ & $\begin{array}{l}15 \\
15\end{array}$ & $\begin{array}{l}40 \\
12\end{array}$ & 2 & 13 & $\begin{array}{r}5 \\
15\end{array}$ & $\begin{array}{l}11 \\
18\end{array}$ & 5 & 8 \\
\hline Cloransulam & 3 & 0 & 5 & 0 & 1 & 0 & 3 & 19 & 17 & 9 & 0 & 10 & 0 & 0 & 12 & 0 \\
\hline Flumioxazin & 8 & 6 & 19 & 4 & 3 & 16 & 17 & 25 & 13 & 32 & 4 & 30 & 18 & 13 & 12 & 18 \\
\hline Fomesafen & 3 & 3 & 41 & 33 & 4 & 8 & 10 & 32 & 22 & 15 & 12 & 31 & 8 & 12 & 3 & 0 \\
\hline Fomesafen $+S$-metolachlor & 4 & 0 & 19 & 43 & 8 & 0 & 3 & 17 & 17 & 23 & 0 & 12 & 20 & 14 & 2 & 4 \\
\hline Imazethapyr & 1 & 3 & 32 & 39 & 4 & 20 & 7 & 38 & 17 & 52 & 7 & 25 & 14 & 2 & 8 & 0 \\
\hline Lactofen & 2 & 1 & 6 & 0 & 6 & 5 & 1 & 15 & 6 & 6 & 0 & 22 & 6 & 2 & 0 & 4 \\
\hline Metribuzin & 0 & 7 & 13 & 13 & 0 & 2 & 14 & 21 & 2 & 15 & 15 & 30 & 13 & 8 & 1 & 1 \\
\hline Pyroxasulfone & 4 & 6 & 3 & 1 & 9 & 23 & 13 & 17 & 45 & 68 & 5 & 17 & 68 & 82 & 7 & 2 \\
\hline$S$-metolachlor & 6 & 3 & 12 & 7 & 12 & 24 & 3 & 18 & 14 & 22 & 0 & 14 & 17 & 25 & 9 & 4 \\
\hline Sulfentrazone & 13 & 9 & 19 & 13 & 13 & 33 & 8 & 17 & 19 & 25 & 3 & 28 & 19 & 33 & 14 & 6 \\
\hline Sulfentrazone + cloransulam & 1 & 2 & 4 & 1 & 11 & 9 & 12 & 38 & 9 & 23 & 0 & 17 & 18 & 2 & 0 & 4 \\
\hline LSD (0.05): & 17 & 26 & 17 & 26 & 17 & 26 & 17 & 26 & 17 & 26 & 17 & 26 & 17 & 26 & 17 & 26 \\
\hline
\end{tabular}


Table 7. Cover crop stand and biomass reduction 28 days after emergence averaged across all herbicide treatments in 2014 and 2015 in corn and soybean experiments in Columbia, Missouri.

\begin{tabular}{|c|c|c|c|c|c|}
\hline \multirow[b]{3}{*}{ Cover crop } & \multicolumn{2}{|c|}{ Soybean experiment } & \multicolumn{3}{|c|}{ Corn experiment } \\
\hline & \multicolumn{4}{|c|}{2014} & \multirow{2}{*}{$\frac{2015}{\text { Stand }}$} \\
\hline & Biomass & Stand & Biomass & Stand & \\
\hline & & $-\% \mathrm{R}$ & eduction & & \\
\hline Austrian winter pea & 30 & 5 & 15 & 8 & 19 \\
\hline Cereal rye & 17 & 11 & 10 & 13 & 13 \\
\hline Crimson clover & 30 & 22 & 10 & 9 & 12 \\
\hline Hairy vetch & 8 & 6 & 12 & 12 & 6 \\
\hline Italian ryegrass & 9 & 5 & 21 & 6 & 14 \\
\hline Oilseed radish & 29 & 14 & 17 & 14 & 6 \\
\hline Winter oat & 15 & 18 & 17 & 15 & 21 \\
\hline Winter wheat & 28 & 16 & 14 & 16 & 10 \\
\hline LSD (0.05): & 9 & 7 & 7 & 8 & 5 \\
\hline
\end{tabular}

of this herbicide. In 2015, sulfentrazone reduced stand density and biomass by $19 \%$ and $33 \%$, respectively, but no significant carryover injury was observed in 2013 following a PRE application of this herbicide.

In 2013 , hairy vetch biomass was reduced $31 \%$ to $49 \%$ following metribuzin, $S$-metolachlor, acetochlor, and pyroxasulfone, while flumioxazin reduced biomass by $24 \%$; however, no herbicide resulted in carryover symptoms in 2015 (Tables 5 and 6). In addition, hairy vetch only exhibited a $7 \%$ and $6 \%$ reduction in biomass and stand density, respectively, across all herbicides in 2014 (Table 8). Hairy vetch proved to be one of the cover crop species least affected by herbicide carryover in these experiments.

Carryover of Corn Herbicides. There was a cover crop species by herbicide treatment interaction for corn herbicides in 2013, but not in 2014 or 2015 (Table 4). However, the main effect of cover crop species was significant in 2014 for stand and biomass reduction and for stand reduction in 2015. In a similar manner, the main effect of herbicide treatment was significant for stand and biomass reduction in 2014 and 2015, respectively. Rainfall from herbicide application to cover crop planting date was 362 and $331 \mathrm{~cm}$ in 2014 and 2015, respectively, but only $96 \mathrm{~cm}$ in 2013 (Table 1). This deficiency in rainfall helps to explain the cover crop by herbicide interaction observed in 2013.

Following nicosulfuron, winter wheat stand density and biomass were reduced by $27 \%$ and
Table 8. Influence of soybean herbicides on the stand reduction of all cover crop species 28 days after emergence at Columbia, Missouri in 2014.

\begin{tabular}{lc}
\hline Herbicide & \% Reduction \\
\hline Acetochlor & 10 \\
Chlorimuron & 26 \\
Chlorimuron + thifensulfuron & 13 \\
Cloransulam & 19 \\
Flumioxazin & 24 \\
Fomesafen & 21 \\
Fomesafen + S-metolachlor & 28 \\
Imazethapyr & 25 \\
Lactofen & 3 \\
Metribuzin & 23 \\
Pyroxasulfone & 32 \\
S-metolachlor & 15 \\
Sulfentrazone & 31 \\
Sulfentrazone + cloransulam & 21 \\
$\quad$ LSD (0.05): & 9 \\
\hline
\end{tabular}

$54 \%$, respectively, while no other herbicides reduced winter wheat stand density in 2013 (Table 9). The observed winter wheat stand and biomass reduction following nicosulfuron is consistent with the 4 mo rotational restriction stated on the herbicide label (Anonymous 2016a). In addition, when averaged across all herbicide treatments, winter wheat stand density was reduced by $16 \%$ and $10 \%$ in 2014 and 2015 , respectively (Table 10 ). Winter wheat biomass was reduced similarly following atrazine, topramazone, isoxaflutole, flumetsulam, rimsulfuron, and clopyralid + acetochlor + flumetsulam + atrazine in 2013.

Flumetsulam reduced oilseed radish stand density by $55 \%$, while flumetsulam and clopyralid + acetochlor + flumetsulam + atrazine resulted in an $80 \%$ and $56 \%$ biomass reduction, respectively (Table 9). The flumetsulam herbicide label lists a 26 mo rotational restriction for canola (Brassica napus L.), which is likely to have similar herbicidal sensitivity as oilseed radish (Anonymous 2016c). Shaner et al. (2014) also reported that across 23 soils, the half-life for flumetsulam ranged from $2 \mathrm{wk}$ to 4 mo, with $80 \%$ of soils having a 2 -mo half-life. Topramazone, isoxaflutole, and rimsulfuron also reduced oilseed radish biomass by $33 \%$ to $36 \%$ in 2013 , but had no negative effect on stand density.

As in the soybean experiment, cereal rye showed very few herbicide carryover symptoms in the corn experiment (Table 9). Biomass and stand reduction did not exceed $13 \%$ when averaged across all 


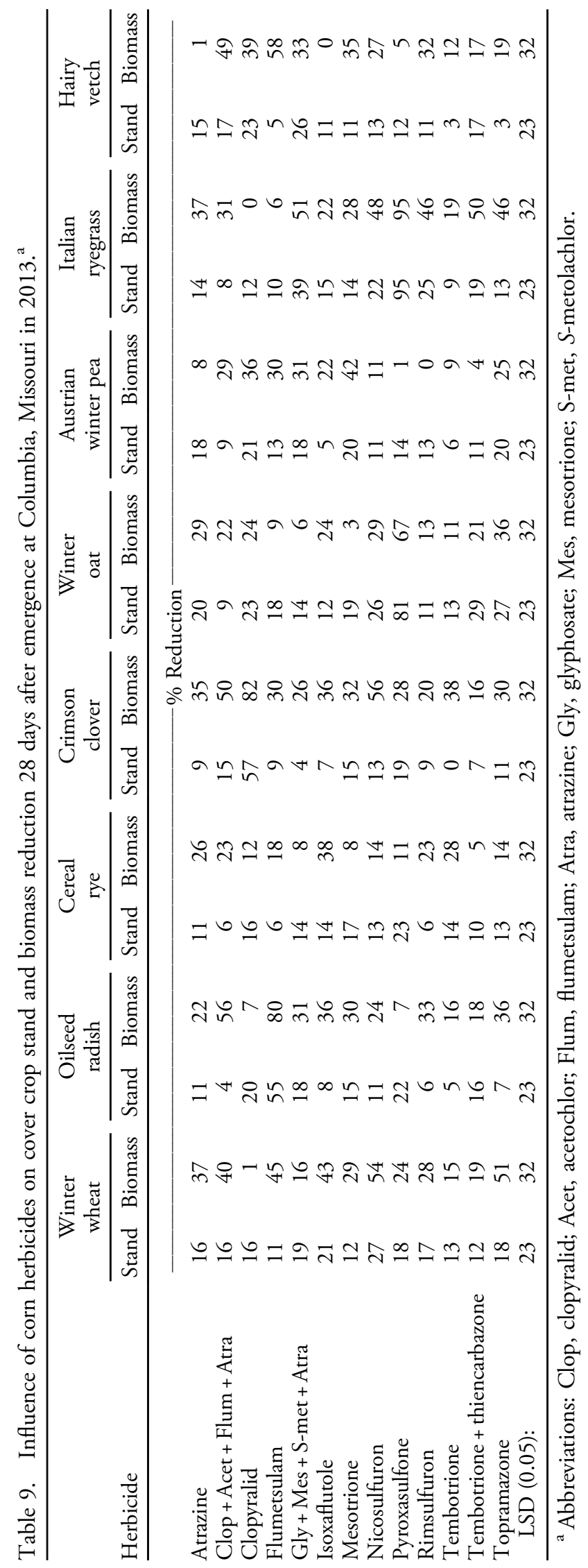

Table 10. Influence of corn herbicides on the biomass and stand reduction of all cover crop species 28 days after emergence at Columbia, Missouri in 2014 and 2015.

\begin{tabular}{lcr}
\hline Herbicide & $\begin{array}{c}\text { Biomass } \\
2015\end{array}$ & $\begin{array}{c}\text { Stand } \\
2014\end{array}$ \\
\hline & $-\%$ Reduction- \\
Acetochlor + clopyralid + flumetsulam & 20 & 6 \\
$\quad+$ atrazine & & \\
Atrazine & 14 & 15 \\
Clopyralid & 16 & 16 \\
Flumetsulam & 8 & 7 \\
Glyphosate + S-metolachlor + glyphosate & 23 & 9 \\
$\quad+$ mesotrione & & \\
Isoxaflutole & 12 & 12 \\
Mesotrione & 11 & 5 \\
Nicosulfuron & 12 & 26 \\
Pyroxasulfone & 11 & 6 \\
Rimsulfuron & 18 & 14 \\
Tembotrione & 17 & 12 \\
Thiencarbazone + tembotrione & 13 & 12 \\
Topramazone & 16 & 11 \\
$\quad$ LSD (0.05): & 9 & 8 \\
\hline
\end{tabular}

herbicide treatments in 2015 (Table 10). However, isoxaflutole reduced cereal rye biomass by $38 \%$ in 2013. Smith et al. (2015) also reported that cereal rye was not impacted by commonly used corn herbicides in a two-year study.

Clopyralid reduced crimson clover biomass and stand by $82 \%$ and $57 \%$, respectively (Table 9). Nicosulfuron and clopyralid + acetochlor + flumetsulam + atrazine also reduced crimson clover biomass by $56 \%$ and $50 \%$, respectively, while atrazine, tembotrione, and isoxaflutole reduced biomass by $35 \%$ to $38 \%$. The observed carryover from clopyralid can be associated with its 12- to 70-d soil half-life (Shaner et al. 2014) and the sensitivity of the clover species to this synthetic auxin herbicide.

Winter oat biomass and stand was reduced by $67 \%$ and $81 \%$, respectively, following in-season applications of pyroxasulfone (Table 9). When averaged across all cover crop species, pyroxasulfone also resulted in a 32\% stand reduction in 2014 (Table 8). Topramazone also reduced winter oat biomass by $36 \%$, which was comparable to the reduction observed following pyroxasulfone. However, topramazone resulted in a $27 \%$ winter oat stand reduction, which was a lower level of stand reduction relative to pyroxasulfone.

Austrian winter pea stand was not affected by any herbicides, but mesotrione and clopyralid reduced 
biomass by $42 \%$ and $36 \%$, respectively (Table 9). Shaner et al. (2014) lists Austrian winter pea as susceptible to clopyralid with a rotational restriction of $18 \mathrm{mo}$ and states that the soil half-life for clopyralid is dependent on soil and climatic conditions.

As in the soybean experiment, pyroxasulfone resulted in the highest level of Italian ryegrass stand and biomass reduction ( $95 \%$ for both) in the corn experiment (Table 9). Atrazine, topramazone, rimsulfuron, nicosulfuron, glyphosate + mesotrione + $S$-metolachlor + atrazine, and tembotrione + thiencarbazone resulted in $37 \%$ to $51 \%$ Italian ryegrass biomass reduction, but these levels of reduction were lower than those observed with pyroxasulfone. In addition to biomass reduction, rimsulfuron and glyphosate + mesotrione $+S$ metolachlor +atrazine also resulted in stand reductions of $25 \%$ and $39 \%$, respectively.

Hairy vetch stand and biomass were reduced by $26 \%$ and $33 \%$ following glyphosate + mesotrione + $S$-metolachlor + atrazine (Table 9). Although no other herbicide treatment reduced hairy vetch stand, mesotrione, clopyralid, flumetsulam, and clopyralid + acetochlor + flumetsulam + atrazine resulted in a $35 \%$ to $58 \%$ biomass reduction. Each herbicide treatment that contained clopyralid or flumetsulam, either as stand-alone treatments or in combination with other herbicides, resulted in biomass reduction of hairy vetch. Therefore, herbicide applications containing either active ingredient should be avoided when establishing hairy vetch as a cover crop.

In conclusion, all herbicides evaluated, excluding lactofen, resulted in biomass or stand reduction of at least one cover crop. However, for each cover crop evaluated there were herbicide treatments that did not result in biomass or stand reduction. Italian ryegrass, oilseed radish, winter oat, and crimson clover, exhibited the highest levels of stand and biomass reduction in both experiments. In contrast, cereal rye was only impacted by 5 out of the 29 total herbicide treatments evaluated in these experiments. Additionally, none of the soybean herbicide treatments caused a stand or biomass reduction in consecutive years, and isoxaflutole was the only corn herbicide to significantly reduce cereal rye biomass. Previous research has shown that cereal rye has several agronomic benefits, such as reducing soil erosion, suppressing weed emergence, and increasing soil organic matter (Kuo et al. 1997; Sainju and
Singh 1997; Webster et al. 2013). The fact that cereal rye can be effectively established following treatment with several corn and soybean herbicides should be considered as an additional benefit of the use of this species. These results indicate that certain residual herbicides have the potential to reduce stand and biomass of fall-seeded cover crops, but herbicide carryover is heavily dependent on rainfall after herbicide application. Additional research is needed to determine how much time and rainfall are needed prior to cover crop establishment following specific herbicide applications.

\section{Literature Cited}

Anonymous. (2016a) Accent ${ }^{\circledR} \mathrm{Q}$ herbicide product label. http:// www.cdms.net/ldat/ld8RQ004.pdf. Accessed March 14, 2016

Anonymous. (2016b) Flexstar ${ }^{\circledR}$ herbicide product label. http:// www.cdms.net/ldat/ld6BM004.pdf. Accessed March 14, 2016

Anonymous. (2016c) Python ${ }^{\circledR}$ herbicide product label. http:// www.cdms.net/ldat/ld0KP016.pdf. Accessed March 14, 2016

Anonymous. (2016d) Sencor ${ }^{\circledR}$ 75DF herbicide product label. http://www.cdms.net/ldat/ld86D003.pdf. Accessed March 14, 2016

Anonymous. (2016e) Valor ${ }^{\circledR}$ SX herbicide product label. http:// www.cdms.net/ldat/ld3LL001.pdf. Accessed March 14, 2016

Anonymous. (2016f) Warrant ${ }^{\circledR}$ herbicide product label. http:// www.cdms.net/ldat/ld9KA005.pdf. Accessed March 14, 2016

Bauer U, Calvet R (1999) Fate of soil applied herbicides: experimental data and predictors of dissipation kinetics. J Environ Qual 28:1765-1777

Bond JA, Eubank TW, Bond RC, Golden BR, Edwards HM (2014) Glyphosate-resistant Italian ryegrass (Lolium perenne ssp. multiflorum) control with fall-applied residual herbicides. Weed Technol 28:361-370

Cantwell JR, Liebl RA, Slife FW (1989) Biodegradation characteristics of imazaquin and imazethapyr. Weed Sci 37:815-819

Curran WS (2001) Persistence of herbicides in soils, PennState Extension. http://extension.psu.edu/pests/weeds/control/persistanceof-herbicides-in-soil. Accessed June 21, 2015

Curran WS, Lingenfelter DD, Wagoner P (1996) Cover crops for conservation tillage systems, Pennsylvania State University. http://extension.psu.edu/plants/crops/soil-management/conservationtillage/cover-crops-for-conservation-tillage-systems. Accessed December 20, 2015

Hager AG, Wax LM, Bollero GA, Stoller EW (2003) Influence of diphenylether herbicide application rate and timing on common waterhemp (Amaranthus rudis) control in soybean (Glycine max). Weed Technol 17:14-20

Hanson BD, Thill DC (2001) Effects of imazethapyr and pendimethalin on lentil (Lens culinaris), pea (Pisum sativum), and a subsequent winter wheat (Triticum aestivum) crop. Weed Technol 15:190-194

Heap I (2016) The International Survey of Herbicide Resistant Weeds. http://www.weedscience.org/summary/home.aspx. Accessed December 1, 2016 
Kells JJ, Leep RH, Tesar MB, Leavitt RA, Cudnohufsky J (1990) Effect of atrazine and tillage on alfalfa (Medicago sativa) establishment in corn (Zea mays)-alfalfa rotation. Weed Technol 4:360-365

Kerr GW, Stahlman PW, Dille JA (2004) Soil pH and cation exchange capacity affects sunflower tolerance to sulfentrazone. Weed Technol 18:243-247

Kuo S, Sainju UM, Jellum EJ (1997) Winter cover cropping influence on nitrogen in soil. Soil Sci Soc Am J 61:1392-1399

Locke MA, Bryson CT (1997) Herbicide-soil interactions in reduced tillage and plant residue management systems. Weed Sci 45:307-320

Loux MM, Reese KD (1993) Effect of soil type and $\mathrm{pH}$ on persistence and carryover of imidazolinone herbicides. Weed Technol 7:452-458

Mueller TC, Boswell BW, Mueller SS, Steckel LE (2014) Dissipation of fomesafen, saflufenacil, sulfentrazone, and flumioxazin from a Tennessee soil under field conditions. Weed Sci 62:664-671

Riggins CW, Tranel PJ (2012) Will the Amaranthus tuberculatus resistance mechanism to PPO-inhibiting herbicides evolve in other Amaranthus species? Int J Agron 2012:1-7

Sainju UM, Singh BP (1997) Winter cover crops for sustainable agriculture systems: influence on soil properties, water quality, and crop yields. Hort Sci 32:21-28

Shaner DL, Jachetta JJ, Senseman S, Burke I, Hanson B, Jugulam M, Tan S, Reynolds J, Strek H, McAllister R, Green J, Glenn B, Turner P, Pawlak J (2014) Herbicide Handbook. 10th edn. Lawrence, KS: Weed Science Society of America. Pp 232, 344

Smith DH, Legleiter TR, Bosak EJ, Johnson W, Davis VM (2015) Cover crop establishment issues following corn and soybean in the upper Midwest. Abstract 174 in Proceedings of the 2015 Weed Science Society of America annual meeting. Lexington, KY: Weed Science Society of America
[SARE] Sustainable Agriculture Research and Education. (2014) Cover Crop Survey. http://www.sare.org/Learning-Center/ From-the-Field/North-Central-SARE-From-the-Field/2013-14Cover-Crops-Survey-Analysis. Accessed March 20, 2015

Tharp BE, Kells JJ (2000) Effect of soil applied herbicides on establishment of cover crop species. Weed Technol 14: 596-601

[USDA] US Department of Agriculture. (2015) Agricultural Resource Management Survey, Crop Production Practices for Soybeans. http://www.ers.usda.gov/data-products/arms-farmfinancial-and-crop-production-practices/tailored-reports-farmstructure-and-finance.aspx. Accessed August 17, 2015

Walsh JD, DeFelice MS, Sims BD (1993a) Impact of tillage on soybean herbicide carryover to grass and legume forage crops in Missouri. Weed Sci 41:144-149

Walsh JD, DeFelice MS, Sims BD (1993b) Soybean (Glycine max) herbicide carryover to grain and fiber crops. Weed Technol 7:625-632

Webster TM, Scully BT, Grey TL, Culpepper AS (2013) Winter cover crops influence Amaranthus palmeri establishment. Crop Prot 52:130-135

Westra EP, Shaner DL, Westra PH, Chapman PL (2014) Dissipation and leaching of pyroxasulfone and $S$-metolachlor. Weed Technol 28:72-81

Zimdahl RL (2007) Fundamentals of Weed Science. 3rd edn. San Diego, CA: Elsevier. Pp 477-481

Zimdahl RL, Catizone P, Butcher AC (1984) Degradation of pendimethalin in soil. Weed Sci 32:408-412

Received April 20, 2016, and approved August 19, 2016.

Associate Editor for this paper: Lawrence E. Steckel, University of Tennessee 